\title{
Spatial patterns of water quality in Xingu River Basin (Amazonia) prior to the Belo Monte dam impoundment
}

\author{
Rodrigues-Filho, JL. ${ }^{a b^{*}}$, Abe, DS. ${ }^{a}$, Gatti-Junior, P. ${ }^{a}$, Medeiros, GR. ${ }^{a}$, Degani, RM. ${ }^{a}$, \\ Blanco, FP. ${ }^{a}$, Faria, CRL. ${ }^{a}$, Campanelli, L. ${ }^{a}$, Soares, FS. ${ }^{a}$, Sidagis-Galli, CV. , \\ Teixeira-Silva, $V^{a}$, Tundisi, JEM. ${ }^{a}$, Matsmura-Tundisi, T. $^{a}$ and Tundisi, JG. ${ }^{a}$ \\ anstituto Internacional de Ecologia e Gerenciamento Ambiental - IIEGA, \\ Rua Bento Carlos, 750, Centro, CEP 13560-660, São Carlos, SP, Brazil \\ ${ }^{\text {b}}$ Departamento de Engenharia de Pesca, Laboratório de Ecologia, Centro de Educação Superior da Região Sul - CERES, \\ Universidade do Estado Estadual de Santa Catarina - UDESC, Rua Cel. Fernandes Martins, 270, Progresso, \\ CEP 88790-000, Laguna, SC, Brazil \\ *e-mail: jorlrf@gmail.com
}

Received: December 15, 2014 - Accepted: May 15, 2015 - Distributed: August 31, 2015

(With 4 figures)

\begin{abstract}
The Xingu River, one of the most important of the Amazon Basin, is characterized by clear and transparent waters that drain a $509.685 \mathrm{~km}^{2}$ watershed with distinct hydrological and ecological conditions and anthropogenic pressures along its course. As in other basins of the Amazon system, studies in the Xingu are scarce. Furthermore, the eminent construction of the Belo Monte for hydropower production, which will alter the environmental conditions in the basin in its lower middle portion, denotes high importance of studies that generate relevant information that may subsidize a more balanced and equitable development in the Amazon region. Thus, the aim of this study was to analyze the water quality in the Xingu River and its tributaries focusing on spatial patterns by the use of multivariate statistical techniques, identifying which water quality parameters were more important for the environmental changes in the watershed. Data sampling were carried out during two complete hydrological cycles in twenty-five sampling stations. The data of twenty seven variables were analyzed by Spearman's correlation coefficients, cluster analysis (CA), and principal component analysis (PCA). The results showed a high auto-correlation between variables $(>0.7)$. These variables were removed from multivariate analyzes because they provided redundant information about the environment. The CA resulted in the formation of six clusters, which were clearly observed in the PCA and were characterized by different water quality. The statistical results allowed to identify a high spatial variation in the water quality, which were related to specific features of the environment, different uses, influences of anthropogenic activities and geochemical characteristics of the drained basins. It was also demonstrated that most of the sampling stations in the Xingu River basin showed good water quality, due to the absence of local impacts and high power of depuration of the river itself.
\end{abstract}

Keywords: watershed, limnology, water quality, Amazonian rivers, hydropower dam.

\section{Padrões espaciais de qualidade de água na Bacia do Rio Xingu (Amazônia) anteriores a barragem de Belo Monte}

\section{Resumo}

O rio Xingu, um dos mais importantes rios que constituem a bacia amazônica, é caracterizado por águas claras e transparentes que drenam uma bacia hidrográfica de $509,685 \mathrm{~km}^{2}$ com distintas condições hidrológicas, ecológicas e pressões antrópicas ao longo de seu percurso. Assim como nas demais bacias hidrográficas da Amazônia, os estudos no Xingu são raros. A eminente construção da Usina hidrelétrica de Belo Monte, a qual alterará as condições ambientais na bacia, demanda também a realização de estudos que gerem informações relevantes e que forneçam subsídios para um desenvolvimento mais equilibrado e igualitário região amazônica. Desta maneira, o objetivo deste trabalho foi analisar a qualidade de água no rio Xingu e em seus tributários focando em padrões espaciais na área de estudo pelo uso de técnicas de estatística multivariada, identificando quais parâmetros são mais relevantes nas condições de qualidade de água na bacia hidrográfica. As coletas de dados ocorreram durante dois ciclos hidrológicos completos em vinte e cinco estações de amostragem. Os dados de vinte e sete variáveis foram analisados pelos coeficientes de correlação de Spearman, análise Cluster (CA), e análise de componentes principais (PCA). Os resultados apontaram para um elevado contingente de variáveis com elevada correlação entre si $(>0,7)$, sendo que estas altas variáveis foram retiradas das análises multivariadas por fornecerem informações ecológicas redundantes sobre o ambiente estudado. A CA resultou 
na formação de 6 agrupamentos, os quais foram observados por possuírem qualidade de água consideravelmente distintas pela PCA. Os resultados estatísticos permitiram identificar uma alta variação espacial da qualidade de água superficial na bacia estudada, sendo estas ocasionadas por especificidades do entorno, diferentes usos da água locais, influências de atividades antrópicas e características geoquímicas das bacias drenadas. Pode-se também evidenciar que em grande parte das estações de coleta na bacia do rio Xingu a qualidade de água superficial foi elevada, decorrente da ausência de impactos locais e do alto poder de depuração do rio.

Palavras-chave: bacia hidrográfica, limnologia, qualidade de água, rios amazônicos, hidrelétrica.

\section{Introduction}

The Amazon Basin is the largest fluvial system in the world $\left(7,008,370 \mathrm{~km}^{2}\right)$, and comprehends a wide variety of rivers with different physical and chemical characteristics influenced by the geochemical composition and the topology of its particular drainage area (Sioli, 1950; ANA, 2011). One of the main right bank tributaries of the Amazon Basin is the Xingu River, which is characterized by having clear and transparent waters and a watershed that drains 509.685 $\mathrm{km}$ including different geological substrates: Precambrian rocks of the upper Paraguay Basin, sediments of the Paraguay and Parecis (Upper Xingu) basins; large tracts of Precambrian rocks of igneous metamorphic complex of southern Amazonian Basin (middle Xingu) and sediments of the Amazon Basin (lower Xingu), besides the alluvial deposits that accompany all large tributaries (Fittkau, 1970; Sioli, 1984; ANA, 2011).

Series of geological events occurred from the upper to the lower Xingu River, which led to the formation of numerous waterfalls and rapids (Camargo et al., 2004). In its middle reaches, near to the city of Altamira, the river forms a sharp deflection forming the so-called Volta Grande do Xingu, with large rapids of $85 \mathrm{~m}$ of drop along $160 \mathrm{~km}$ and with varying anastomosing channels (CNEC, 1988; Eletrobrás, 2009; Leme Engenharia, 2009). Currently, the Volta Grande region comprising entire or part of the municipalities of Medicilândia, Brasil Novo, Altamira, Vitória do Xingu, Senador Jose Porfirio and Porto de Moz, as well as different areas of indigenous territories and protected areas (Eletrobrás, 2009), has attracted attention from the academic and the public, by being selected for the installation of the Hydropower Plant of Belo Monte.

Several landscape uses and high hydrological singularity of the rivers stretches cause fluctuations on water quality along watershed, which are accented by complex transient interactions between surface water and riparian environments (Ward et al., 1998). Conditions of topography and land use are also important factors that influence the water quality in lotic environments (Sheldon et al., 2012), requiring the use of methods of study that focus both the ecological and anthropogenic processes occurring in the landscape scale and/or in the watershed as a whole (Likens, 1984; Wiens, 1989; Zalewski, 2000; Turner et al., 2001; Tundisi et al., 2008).

Studies conducted in the basin of the Xingu River that focus on the characteristics or conditions of water resources are scarce. The available information on water quality are concentrated in technical reports (CNEC, 1988; Eletrobrás, 2009; Leme Engenharia, 2009) that even having high quality and quantity of information, were not focused on ecology and limnology aspects.

The hydropower utilization of the Xingu River always was a goal of part of the Brazilian government, but the two initials attempts for building it were not succeeded because the projects were flawed and probably would generate wide environmental, social and economic impacts in area that would be directly and indirectly affected by the construction (Sevá Filho, 2005). On the third attempt, with changes in the construction project and under perspective of detailed studies, the Brazilian environmental agency (IBAMA) provided a license with conditions for construction of Belo Monte hydropower damn (Brasil, 2010). The issuance of this license has generated strong opposition from environmental, indigenous and socials movements, as well a considerable part of the academic community (Santos and Hernández, 2009).

The imminent construction of the Belo Monte dam enhances the importance of studies conducted in this basin. The transformation of lotic to lentic environments by the construction of reservoirs results in changes in the hydrological regime, water quality and ecological conditions that cause considerable changes in the landscape, the hydrosocial cycle and the hydroeconomy of the affected area (Tundisi and Straškraba, 1999).

Thus, a set of strategic studies are necessary in order to generate knowledge about the current situation in the Xingu River, and promote a broader and deeper view of water resources in the region (Tundisi, 2007). In this sense, the focus of this paper is to analyze the water quality of the Xingu River and its tributaries in the Volta Grande region focusing on the spatial patterns in the area by the use of multivariate statistical techniques, as well as identifying which parameters describe better the environmental complexity in the watershed.

\section{Methods}

\subsection{Study area and samples}

The dataset utilized in this paper was obtained from the Project named "Limnologic and Superficial Water Quality Monitoring" which is part of Environmental Basic Project to license the building of Belo Monte hydropower dam. These studies are requirements to obtained the License in electrical projects according Brazilian laws (CONAMA, 1987).

In this study, twenty-five sampling points located in the Xingu River Basin were monitored, being eighteen in the main river, four in urban areas of Altamira (Panelas, 
Ambé and Altamira streams) and Vitória do Xingu (Tucurui Stream), two stations in the Bacajá River and one station in Chocai Stream (Figure 1). The location and characteristics of the surroundings of the monitored points are presented in Tundisi et al. (2015). All stations were located at backwaters places and near-shore regions, where conditions are regionally more representative and homogeneous, away from transient areas such as point source mixing zones.

The dataset was collected during two annual hydrological cycles as part of the "Basic Environmental Project" (PBA) of the Belo Monte Hydroelectric Power Plant. Four field campaigns were carried out in each cycle in the following hydrological seasons: June 2012 (lowering waters), September 2012 (dry), January 2013 (rising waters), April 2013 (flood), July 2013 (ebb), October 2013 (dry), January 2014 (flooding) and April 2014 (flood). All procedures for sampling, preservation and transportation of the samples were according to the standard methods for the examination of water and wastewater (APHA, 1998). Twenty-seven physicochemical parameters (Table 1) were obtained and used for analysis.

\subsection{Data analysis}

The correlation between variables was tested using the Spearman $R$ coefficient as a non-parametric measure of the correlation of water quality data set (raw data) for $0.05 \mathrm{p}$-values of significance by two-tailed test (Zar, 2010). When high positive correlations were recorded, ie Spearman coefficients higher than 0.70 (Ouyanget al., 2006), the variables were identified as "redundant" and only one (the most representative one) of these variables was retained for subsequent multivariate analysis (Legendre and Legendre, 1998). After removal of redundant variables, all dataset was standardized to ensure that all variables have equal weigh through z-scale transformation in order to avoid misclassification due to wide differences in the dimensionality of the data (Simeonova et al., 2003).

We performed cluster analysis (CA) to observe sampling stations relatedness concerning water quality variables analyzed, resulting in clusters that have high internal similarity and low external similarity (ie between groups) (Legendre and Legendre, 1998; Everitt et al., 2001). The clustering method used was the agglomerative hierarchical, allowing the construction of a dendogram from the set of variables analyzed respecting the hierarchy of similarity between the resulting groups. The similarity measure was the Euclidean distance, which is a metric commonly used in studies with multiple variables by being perfectly metric. The association between objects and study groups was estimated by the method of weighted averages (Weigthed Clustering), where the similarity between objects is calculated by summing the weighted similarities. This criterion is especially recognized for producing a faithful representation of the objects within the cluster (Legendre and Legendre, 1998; Everitt et al., 2001). Cluster significance was determined using the criterion of 0.66 Dmax (Simeonova et al., 2003) The cluster analysis was performed with the software Past (Hammer et al., 2001).

After the definition of the clusters formed by sampling stations for CA, a descriptive analysis of the variables of water quality was conducted on each of these groups.

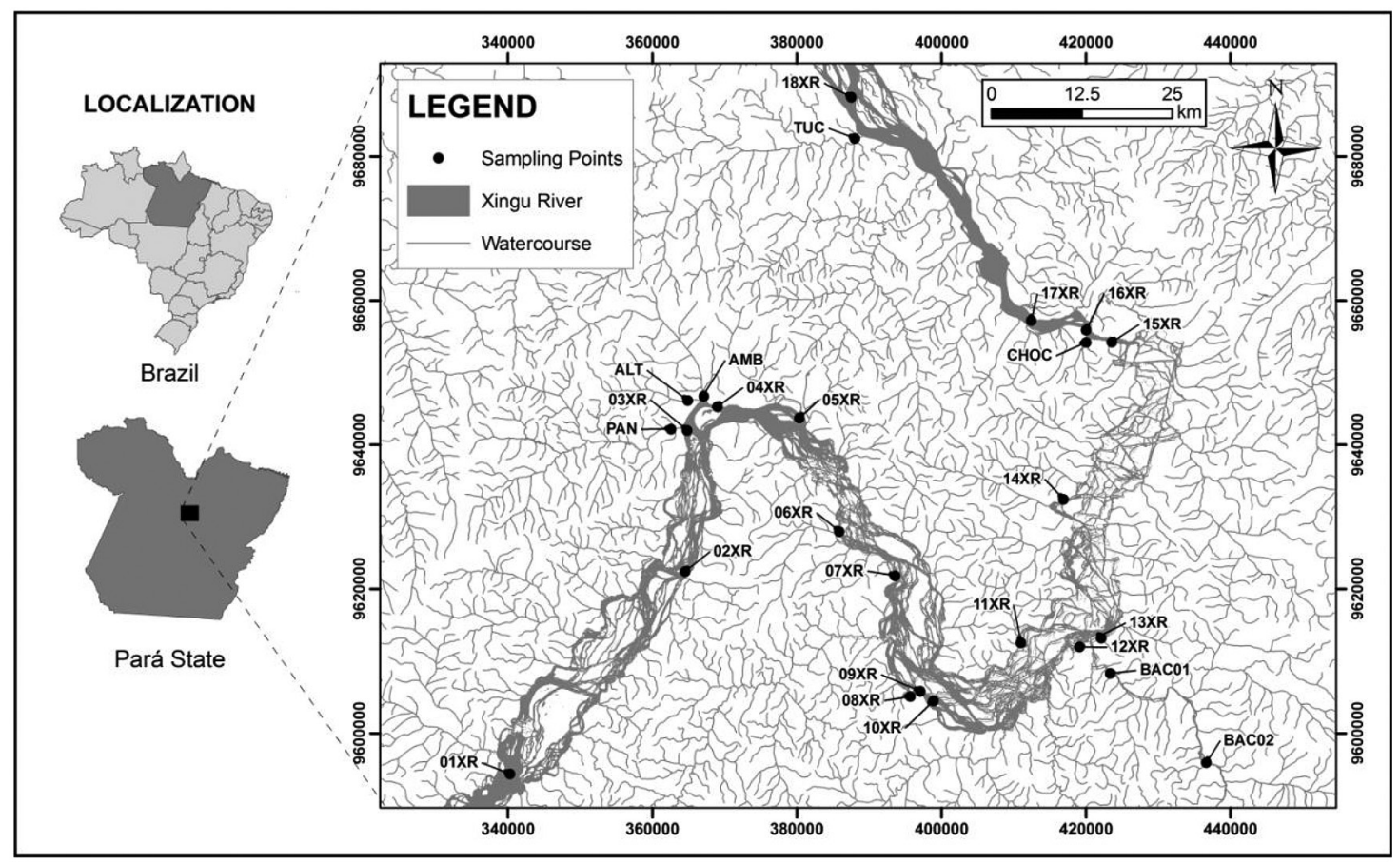

Figure 1. Map showing the monitored stations in the middle-lower portion of the Xingu River Basin. 
Table 1. Physical and chemical variables of water quality measured in the present study.

\begin{tabular}{|c|c|c|c|c|}
\hline Variables & Abreviation & Unit & Method/Equipament & Reference \\
\hline Depth & DEP & $\mathrm{m}$ & Depth gauge & Speedtech Instruments \\
\hline $\mathrm{pH}$ & $\mathrm{pH}$ & $\mathrm{pH}$ & Multiparametric probe & YSI Incorporated \\
\hline Conductivity & COND & $\mathrm{mS} . \mathrm{cm}^{-1}$ & Multiparametric probe & YSI Incorporated \\
\hline Turbidity & TURB & UNT & Multiparametric probe & YSI Incorporated \\
\hline Dissoved Oxigen & DO & mg.L. $\mathrm{L}^{-1}$ & Multiparametric probe & YSI Incorporated \\
\hline Water temperature & TEMP & ${ }^{\circ} \mathrm{C}$ & Multiparametric probe & YSI Incorporated \\
\hline Redox Potential & ORP & $\mathrm{mV}$ & Multiparametric probe & YSI Incorporated \\
\hline Water transparency & TRANSP & $\mathrm{M}$ & Secchi disk & Wetzel and Likens (1991) \\
\hline Alcalinity & ALKAL & $\mathrm{mg}(\mathrm{CaCO} 3) \cdot \mathrm{L}^{-1}$ & $\begin{array}{l}\text { Titration with } \mathrm{H}_{2} \mathrm{SO}_{4} \\
\text { solution }\end{array}$ & APHA (1998) \\
\hline BOD & BOD & $\mathrm{mg} \cdot \mathrm{L}^{-1}$ & Winkler method & APHA (1998) \\
\hline Total phosphorous & $\mathrm{TP}$ & $\operatorname{mg}(\mathrm{P}) \cdot \mathrm{L}^{-1}$ & $\begin{array}{l}\text { Colorimetry method/ } \\
\text { Spectrophotometry }\end{array}$ & Valderrama (1981) \\
\hline $\begin{array}{c}\text { Total Kjeldhal } \\
\text { nitrogen }\end{array}$ & $\mathrm{TN}$ & $\operatorname{mg}(\mathrm{NTK}) \cdot \mathrm{L}^{-1}$ & $\begin{array}{l}\text { Acid digestion and } \\
\text { distillation }\end{array}$ & APHA (1998) \\
\hline Nitrite & $\mathrm{NO}_{2}^{-}$ & $\operatorname{mg}(\mathrm{N}) \cdot \mathrm{L}^{-1}$ & Liquid chromatography & APHA (1998) \\
\hline Nitrate & $\mathrm{NO}_{3}^{-}$ & $\mathrm{mg}(\mathrm{N}) \cdot \mathrm{L}^{-1}$ & Liquid chromatography & APHA (1998) \\
\hline Ammonium & $\mathrm{NH}_{4}+$ & $\operatorname{mg}(\mathrm{N}) \cdot \mathrm{L}^{-1}$ & Liquid chromatography & APHA (1998) \\
\hline Fluoride & $\mathrm{F}^{-}$ & $\operatorname{mg}(\mathrm{F}) \cdot \mathrm{L}^{-1}$ & Liquid chromatography & APHA (1998) \\
\hline Chloride & $\mathrm{Cl}^{-}$ & $\mathrm{mg}(\mathrm{Cl}) \cdot \mathrm{L}^{-1}$ & Liquid chromatography & APHA (1998) \\
\hline Bromide & $\mathrm{Br}^{-}$ & $\operatorname{mg}(\mathrm{Br}) \cdot \mathrm{L}^{-1}$ & Liquid chromatography & APHA (1998) \\
\hline Lithium & $\mathrm{Li}^{+}$ & $\operatorname{mg}(\mathrm{Li}) \cdot \mathrm{L}^{-1}$ & Liquid chromatography & APHA (1998) \\
\hline Sulfate & $\mathrm{SO}_{4}^{-2}$ & $\mathrm{mg}\left(\mathrm{SO}_{4}^{-2}\right) \cdot \mathrm{L}^{-1}$ & Liquid chromatography & APHA (1998) \\
\hline Sodium & $\mathrm{Na}^{+}$ & $\operatorname{mg}(\mathrm{Na}) \cdot \mathrm{L}^{-1}$ & Liquid chromatography & APHA (1998) \\
\hline Potassium & $\mathrm{K}^{+}$ & $\mathrm{mg}(\mathrm{K}) \cdot \mathrm{L}^{-1}$ & Liquid chromatography & APHA (1998) \\
\hline Magnesium & $\mathrm{Mg}^{2+}$ & $\mathrm{mg}(\mathrm{Mg}) \cdot \mathrm{L}^{-1}$ & Liquid chromatography & APHA (1998) \\
\hline Calcium & $\mathrm{Ca}^{2+}$ & $\mathrm{mg}(\mathrm{Ca}) \cdot \mathrm{L}^{-1}$ & Liquid chromatography & APHA (1998) \\
\hline Chlorophyll-a & Chl-a & $\mu \mathrm{g} . \mathrm{L}^{-1}$ & $\begin{array}{c}\text { Extraction in warmed } \\
\text { ethanol/Spectrophotometry }\end{array}$ & Nush (1980) \\
\hline E.coli & E.coli & $\begin{array}{l}\text { NMP. } 100 . \\
\mathrm{mL}^{-1}\end{array}$ & $\begin{array}{c}\text { Incubation in Colilert }^{\circledR} \\
\text { substrate }\end{array}$ & APHA (1998) \\
\hline Cyanophyceae & CYANO & org. $\mathrm{mL}^{-1}$ & Organism count & \\
\hline
\end{tabular}

In this descriptive analysis, the mean, standard deviation and amplitude variation (minimum and maximum) were estimated. Here we chose to use all 27 variables, as studies in the region of the Xingu Basin are rare, and it is important to provide descriptive results, even though not all variables have statistical significance.

Then, a principal component analysis (PCA) was performed to identify which were the most important variables in the CA groups, ie, those responsible for the spatial variation of water quality recorded in the study area. The components generated by PCA were selected by Jolliffe cut-off value, which gives an indication of how many principal components should be considered significant in the analysis by eigenvalues of the components. In this procedure, components with eigenvalues smaller than the Jolliffe cut-off may be considered insignificant and discard because they only account for a small proportion of the variation in datasets (Jolliffe, 1986). The selection of most representative variables was based on the methodology described by B4 Jolliffe (1972), which calls for variable retention in a ratio of $1: 3$ to observations (=25 Sample stations), keeping only those that have the largest factor loading in the components maintained in the PCA. All steps of the PCA were performed with the software XLSTATS version 7.5.2.

\section{Results}

The spatial correlation matrix of the water quality parameters obtained using the Spearmam Coefficient is shown in Table 2 . The 27 variables generated 351 correlation coefficients when analyzed in pairs, and 101 were statistically significant $(p<0.05)$. BOD was the only variable that had no significant correlation with any of the others. The variables that showed only one significant correlation were DEP with TRANSP (0.69), $\mathrm{NH}_{4}^{+}$with TRANSP (0.44) and TN with CYANO (-0.41).

Some variables had a moderate number of significant correlations. The RP had significant positive correlation, only $\mathrm{Li}^{+}(0.46)$, while negative correlations were prevalent, 


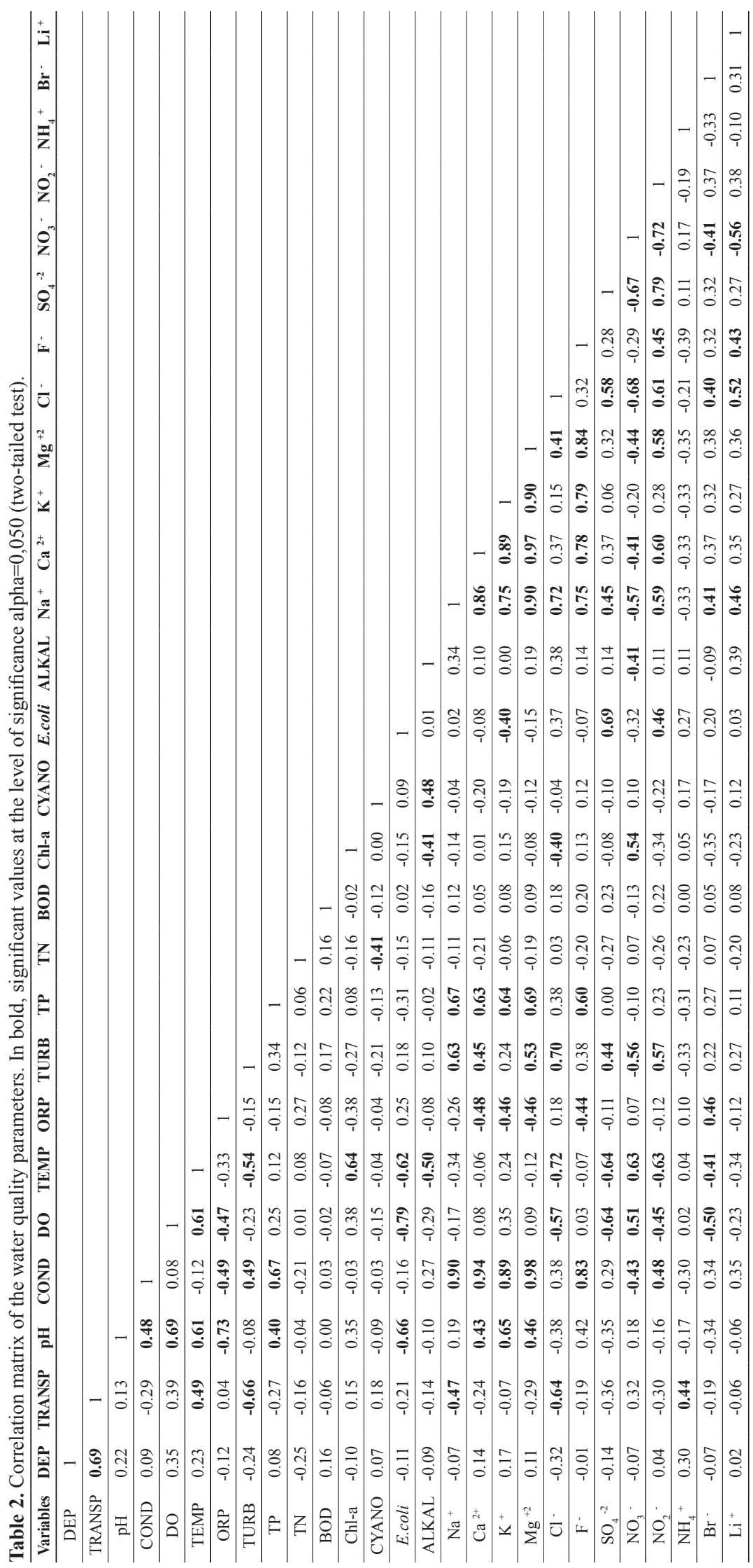


occurring with $\mathrm{Ca}^{2+}(-0,48), \mathrm{K}^{+}(-0,46)$ and $\mathrm{Mg}^{2+}(-0,46), \mathrm{pH}$ $(-0.73)$, COND (-0.49) and DO (-0.47). The concentration of chlorophyll-a (Chl-a) showed positive correlation with water temperature (TEMP) and negative correlation with ALK (-0.40) and $\mathrm{Cl}^{-}(-0.41)$. The E.coli density in the monitored area showed positive correlation with $\mathrm{SO}_{4}^{-2}$ (0.69) and $\mathrm{NO}_{3}^{-}(0.46)$ and negative with $\mathrm{pH}(-0.66)$, DO (-0.64), TEMP (-0.62) and $\mathrm{K}^{+}(-0: 40)$. TP showed significant positive correlation with $\mathrm{Na}^{+}(0.67), \mathrm{Ca}^{2+}(0.64), \mathrm{K}^{+}(0.63)$, $\mathrm{Mg}^{2+}$ (0.69), $\mathrm{Cl}^{-}$(0.60) COND (0.67) and $\mathrm{pH}(0.40)$. $\mathrm{NO}_{3}{ }^{-}$and $\mathrm{NO}_{2}{ }^{-}$showed a significant negative correlation between them (- 0:41), as well as significant correlations with a high number of variables. Examples of the above mentioned pattern were compared with the COND, DO, TURB, TEMP, $\mathrm{Na}^{+}, \mathrm{Ca}^{2+}, \mathrm{K}^{+}, \mathrm{Mg}^{2+}, \mathrm{Cl}^{-}$and $\mathrm{SO}_{4}^{-}$. DO (9), $\mathrm{pH}$ (9) and COND (11) were significantly correlated with a large set of variables. Correlation coefficients (Table 2) were also used to reduce the number of variables for multivariate analyzes, excluding redundant parameters. $\mathrm{Na}^{+}$, $\mathrm{Ca}^{2+}, \mathrm{K}^{+}, \mathrm{Mg}^{2+}$, and $\mathrm{Cl}^{-}$were excluded as they were highly correlated with COND, while F- was excluded due to high correlation with TURB. Thus, from 27 initial variables, 22 were retained for multivariate analysis (CA and PCA).

Cluster analysis was used to detect similarity between samples scattered in space, for grouping of sites in the Xingu River Basin according to their water properties. CA discriminated six (6) significant groups (Figure 2). Cluster 1 consisted of points with high impacted water quality. Such stations are inserted in streams draining urban areas of the city of Altamira (ALT, PAN and AMB) and Vitória do Xingu (TUC). The Cluster 2 was formed by the two stations located in the Bacajá River (BAC02 and BAC01). Cluster 3 showed the highest amount of stations (9) when compared with others. Eight (8) of these stations are included in the Xingu River and in Chocai Stream (CHOC), all of which are inserted in locations with low anthropogenic influences on the environment. In Cluster 4 three (3) sampling stations were grouped, all placed on the Xingu River (13_XR, 14_XR and 18_XR) and near the confluence of a tributary with the main river. Cluster 5 consisted of four (4) stations located on the Xingu River, located downstream of moderate impacts on the water quality. The station 03 XR is located downstream of the confluence with the urban stream Panelas. Stations 08_XR and 10_XR were located downstream of the urban communities of Ressaca and Fazenda stations, while the 11_XR is near the Indian village of Paquiçamba. The last cluster (Cluster 6) was formed by three stations placed on the Xingu River (07_XR,09_XR and 16_XR) that are geographically distant from each other but all are near stretches of higher water velocity.

The descriptive analysis of the variables in the clusters generated by the CA allowed the identification of spatial variations of water quality in the study area (Table 3 ). The Cluster 1 was characterized by having high values of ORP, BOD, E. coli, ALK and ions (e.g. $\mathrm{Li}^{+}$and $\mathrm{Br}$ ) and

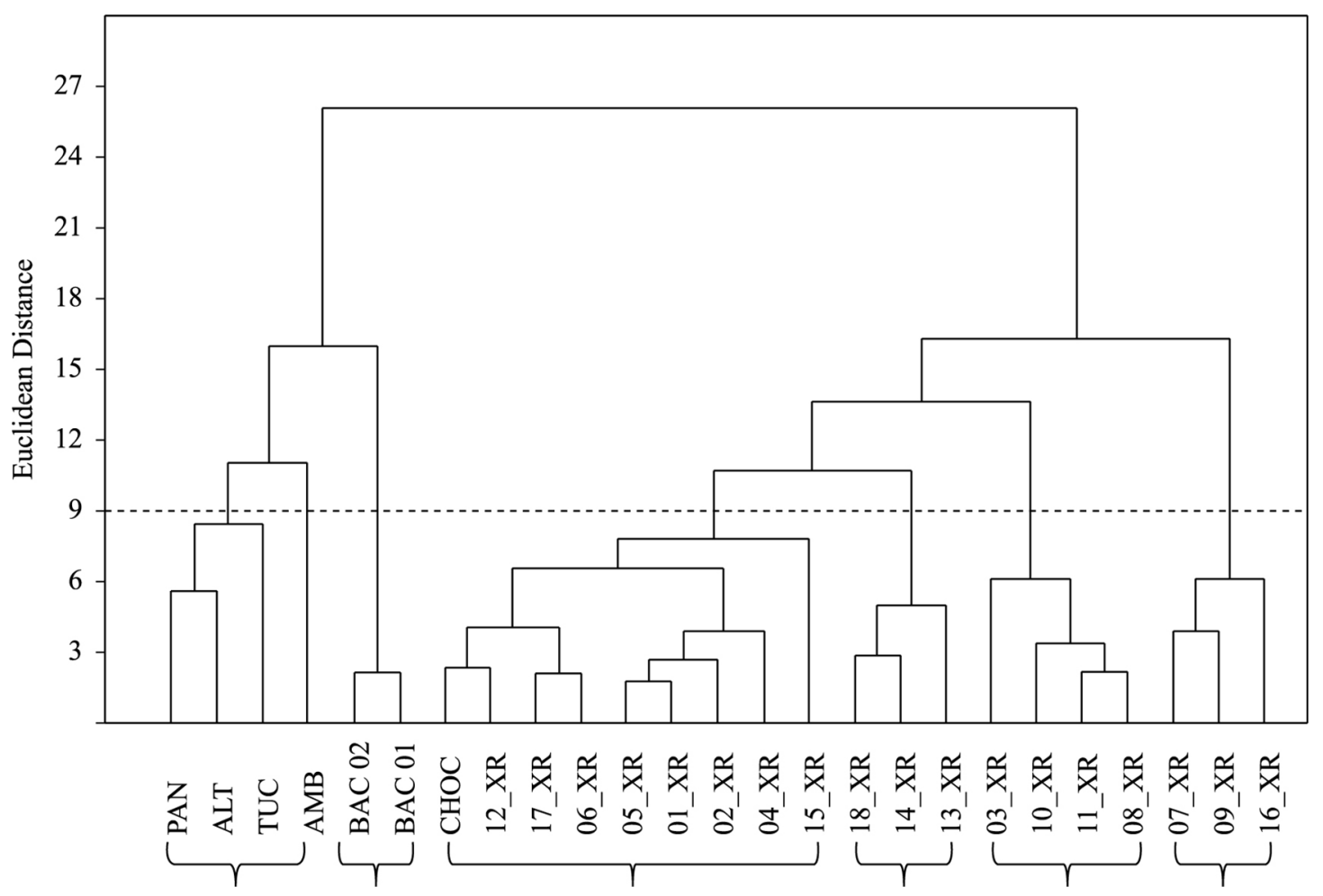

Figure 2. Graphics results of Cluster Analysis for sample sites in the Xingu River Basin. 


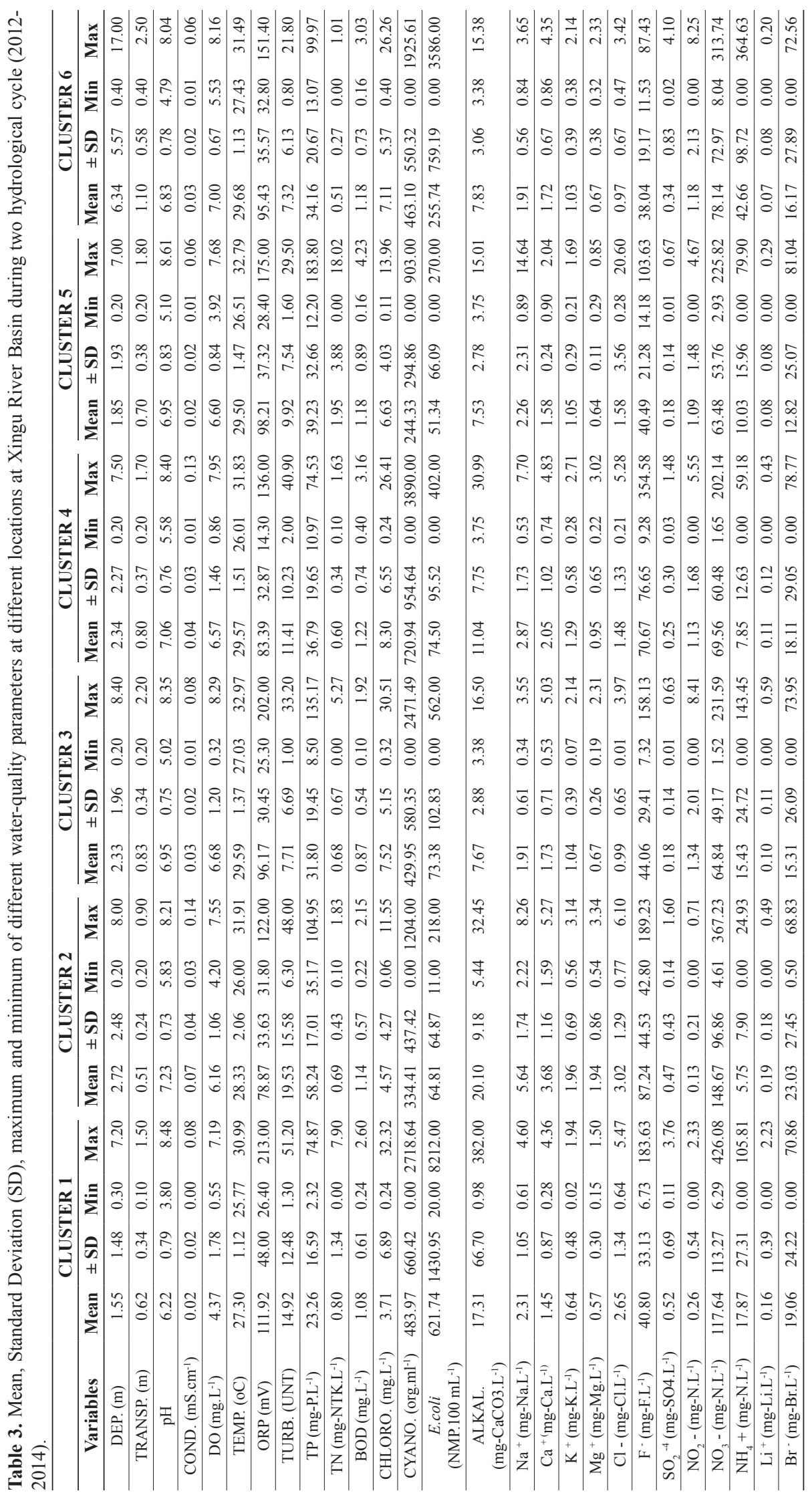


low levels of DO and Chl-a In Cluster 2 were also recorded dissonant conditions, with high COND, PH, TP and ionic concentrations. Cluster 3 comprised predominantly by stations located on the Xingu River, was characterized by having low values of E.coli, ALK and TURB and ionic charges. On the other hand, the variables TEMP $\mathrm{pH}$ and TRANSP reached high values. In Cluster 4 were recorded high densities of CYANO and high BOD, while in Cluster 5 concentration of TN were higher than in the other groups. Cluster 6 was characterized by having high depth, high transparency and high ammonium concentrations comparing to other points. Another observation from the descriptive analysis was that the levels of BOD, Chl-a and $\mathrm{NO}_{2}^{-}$were higher in clusters 4, 5 and 6 than in other points.

The PCA allowed the reduction of the multidimensionality and the identification of the most important variables to describe spatial variations. The eigenvalues generated by the PCA showed a marked decay (Figure 3 ). The first component accounted for $43.77 \%$ of the variability, while the second component accounted for $30.04 \%$. From the third component, which accounted for $13.98 \%$ of the variability, there was a sharp fall in the eingenvalues. The comparison of the curve of eigenvalues with Jolliffe cut-off (Figure 3) pointed out that the first two components generated by PCA were above the hypothetical distribution (Broken - stick distribution), and only those were considered significant in this study.

Factors loadings of the 22 water quality variables estimated for the two retained components are presented in Table 4. According to the methodology, we selected eight variables for the PCA, respecting the proportion of $3: 1$ of observations and variables, respectively. The variables selected were those that showed the largest factor loadings in retained components (1 and 2): Chl-a, COND, E.coli, $\mathrm{NO}_{3}^{-}, \mathrm{NO}_{2}^{-}, \mathrm{pH}, \mathrm{TP}$ and TURB.

The PCA biplot graph with 8 selected parameters indicated a clear spatial pattern in water quality and allowed the identification of the most influent variables of the previously determined clusters in the Xingu River Basin (Figure 4). Stations of Cluster 1, consisting of urban streams, are shown in the lower left side of the graph, which is characterized for having high concentrations of E. coli and $\mathrm{NO}_{2}^{-}$, moderate COND and TURB and low values of $\mathrm{DO}, \mathrm{pH}, \mathrm{Chl}-\mathrm{a}$ and $\mathrm{NO}_{3}^{-}$. The stations of the Bacajá River (Cluster 2) located in the upper left side of the graph, showed the most pronounced levels of cond., TURB and TP. The dots of Cluster 3, which was formed by the stations on the Xingu River and on the Chocai Stream, showed high concentrations of $\mathrm{DO}, \mathrm{NO}_{3}{ }^{-}$and $\mathrm{Chl}-\mathrm{a}$ and low values of the variables COND, TURB, E. coli, and $\mathrm{NO}_{2}^{-}$. The characteristics of Cluster 4 were similar to those described above, with the exception of one of the stations (14_RX), which showed high concentrations of TP and COND in relation to others.

The Cluster 5, consisting of stations located on the Xingu River downstream of anthropogenic impacts, showed concentrations of TP, cond., TURB, $\mathrm{NO}_{2}^{-}$and $E$. coli higher than in the other stations located on the Xingu River. The dots of the Cluster 6 were scattered in the biplot, mainly on the right side of the graph, being characterized by moderate levels of $\mathrm{NO}_{3}^{-}$and $\mathrm{Chl}-\mathrm{a}$.

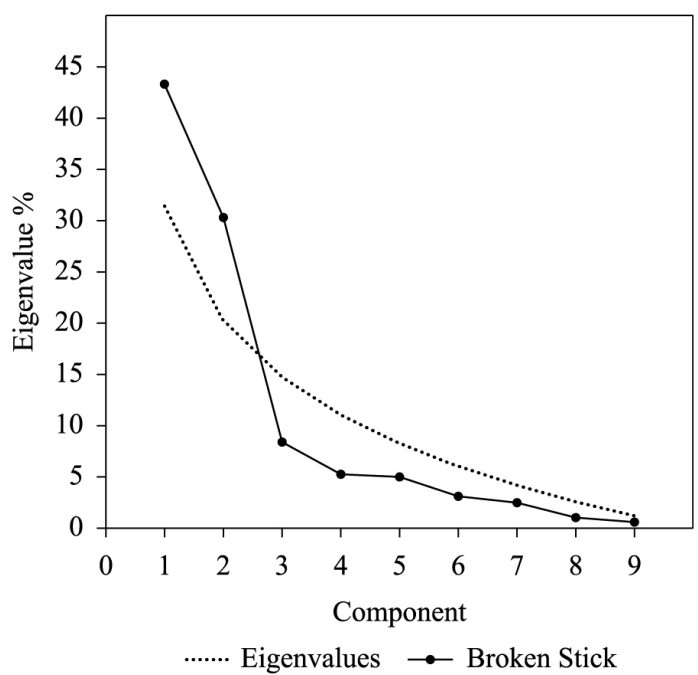

Figure 3. Scree plot of the eigenvalues of principal components (\%) in water quality variables at Xingu River Basin and broken stick distribution.

Table 4. Factors loadings of the water quality variables at Xingu River Basin.

\begin{tabular}{|c|c|c|}
\hline Variables & Component 1 & Component 2 \\
\hline ALKAL & 0.1595 & -0.09981 \\
\hline BOD & 0.07608 & 0.1145 \\
\hline $\mathrm{Br}^{-}$ & 0.1629 & 0.04583 \\
\hline Chl-a & -0.2165 & 0.2859 \\
\hline $\mathrm{Cl}^{-}$ & 0.2566 & -0.07864 \\
\hline COND & 0.2565 & 0.4168 \\
\hline CYANO & -0.05286 & -0.0704 \\
\hline DEP. & -0.03267 & 0.1245 \\
\hline DO & -0.2493 & 0.4211 \\
\hline E.coli & 0.3929 & -0.1463 \\
\hline $\mathrm{Li}^{+}$ & 0.145 & 0.201 \\
\hline $\mathrm{NH}_{4}+$ & -0.1724 & -0.1233 \\
\hline $\mathrm{NO}_{2}^{-}$ & -0.3607 & 0.02634 \\
\hline $\mathrm{NO}_{3}^{-}$ & 0.3393 & 0.0841 \\
\hline $\mathrm{pH}$ & 0.0279 & 0.269 \\
\hline ORP & 0.01379 & -0.5061 \\
\hline $\mathrm{SO}_{2}^{-4}$ & 0.2039 & -0.1895 \\
\hline TEMP & -0.1106 & 0.1949 \\
\hline $\mathrm{TN}$ & -0.01275 & -0.1781 \\
\hline TP & 0.201 & 0.3726 \\
\hline TRANSP & -0.2857 & 0.02009 \\
\hline TURB & 0.3369 & 0.1464 \\
\hline
\end{tabular}

*In bold are the variables selected by B4 methodology (Jolliffe, 1972). 


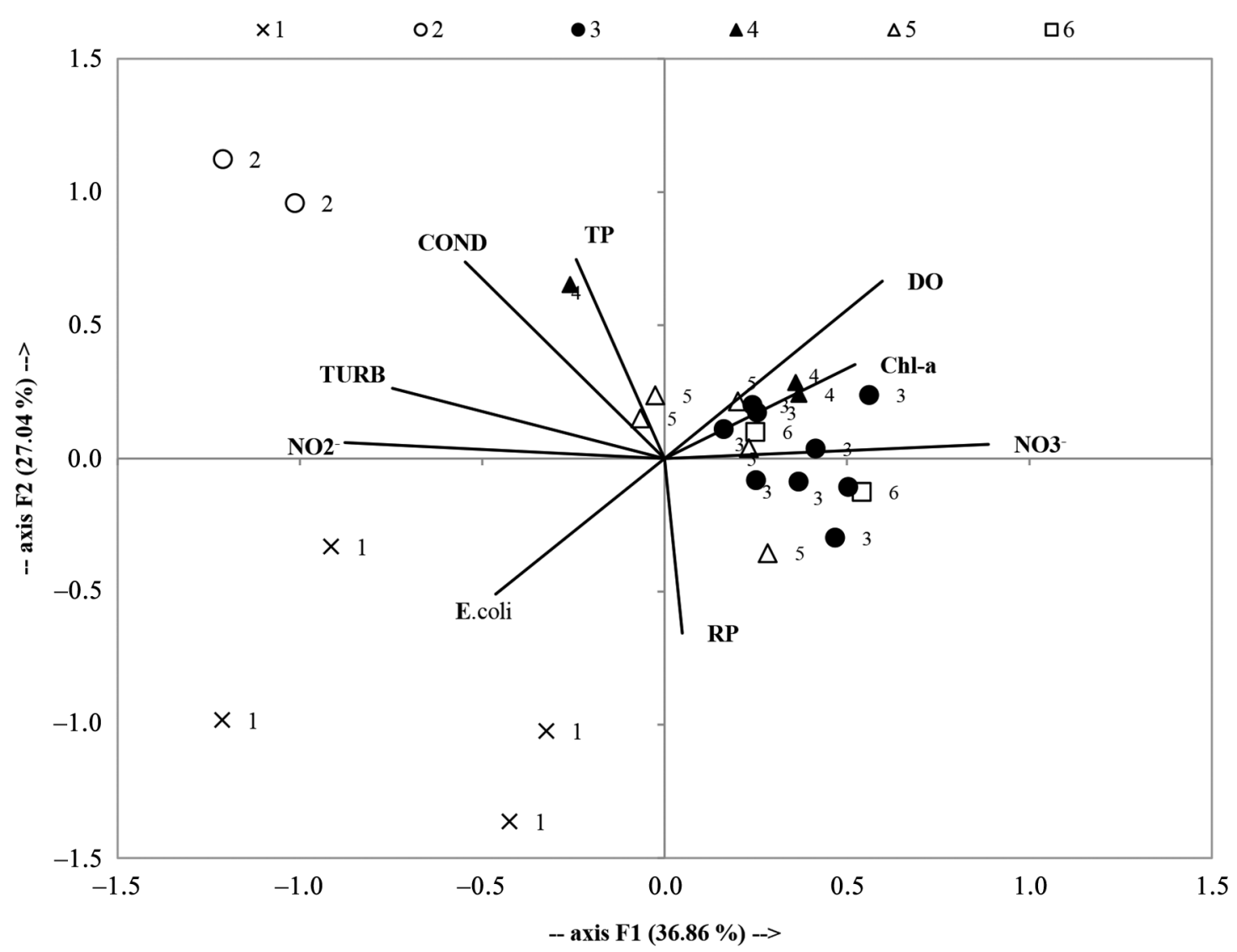

Figure 4. Biplot of the PCA in surface water quality in Xingu River Basin with indication of cluster numbers previously determined by CA.

\section{Discussion}

The surface water quality in the Xingu River basin showed high spatial heterogeneity, being influenced by the conditions of the surroundings and the areas drained by the water bodies analyzed. In fact, it has long been recognized that aquatic ecosystems are strongly influenced by the landscapes through which they flow (Allan, 2004).

The correlations among variables indicate the influence of the environment on the water quality. Variables associated with anthropogenic activities with impact on water quality were positively correlated. That was the case of the correlation of E.coli density and $\mathrm{NO}_{2}^{-}$and $\mathrm{SO}_{4}^{-2}$ concentrations, indicating that those environments receive domestic sewage discharge without pretreatment (Tundisi et al., 2008; Zhao et al., 2011). The correlation of COND with $\mathrm{NO}_{2}^{-}$may also be an indicative of local human impacts. On the other hand, the correlation of COND with the ionic charges of $\mathrm{Na}^{+}, \mathrm{Ca}^{2+}, \mathrm{K}^{+}, \mathrm{Mg}^{2+}$ and $\mathrm{F}^{-}$was apparently linked to the geochemistry of the region. These observations on the conductivity are consistent with literature (Wetzel, 2001) stating that higher conductivity in aquatic systems is commonly related to environments with high trophy or geochemical composition of the drainage basin.
The application of multivariate analysis CA and PCA revealed high spatial heterogeneity concerning water quality. Usually, water quality monitoring includes a large number of variables, which contain rich information about the structure and functioning of the water resources (Iscen et al., 2008). The 25 stations analyzed in the Xingu River Basin were formed six distinct groups (CA corroborated by PCA) and revealed distinct properties of surface water influenced by different factors such as local uses; the characteristics of the surroundings; and the geochemical composition of the drainage basin. Urban streams were the main factor represented in Cluster 1. Urban streams characteristics include a hydrography with several and accentuated alterations, high nutrients and contaminants concentrations, altered channel morphology and reduced biotic richness, with higher dominance of tolerant species (Paul and Meyer, 2001; Meyer et al., 2005). The grouping formed by these streams showed high densities of $E$. coli and loads of ions $\left(\mathrm{SO}_{4}^{-2}, \mathrm{NH}_{4}^{+}\right.$and $\left.\mathrm{NO}_{2}^{-}\right)$, and low concentration of DO and Chl-a. These characteristics indicate that the dumping of untreated sewage from the cities of Altamira (streams Panelas, Ambé and Altamira) and Vitória do Xingu (stream Tucuruí) is the most important factor influencing on the quality of surface water in these locations. The low proportion of homes with proper sewage system and the 
high population growth in the last three years in these cities (IBGE, 2010, 2014) can accentuate the deterioration of these urban streams in a short period of time. However, the construction of sewage systems in these cities, one of the compensatory actions for licensing of the hydroelectric plant of Belo Monte, would improve the sanitary conditions and the water quality of urban streams.

Another group that appeared to be influenced by the proximity to urban areas was the one represented by Cluster 5. Three points from this group, all inserted on the Xingu River, were located near the human communities of Ressaca, Fazenda and Paquiçamba (an indigenous village). These settlements, which, have no sewage system, use waters of Xingu River for domestic activities (e.g. washing clothes and utensils) and are also affected by agricultural and mining activities, being these activities related with appearance clearings in the local vegetation. The deforestation causes topsoil loss, modifies phosphorous and nitrogen cycles and increases the concentration of these nutrients in water bodies (Likens et al., 1970). Also, the presence of these activities around may cause deterioration in local water quality, when compared with other parts of the Xingu River. Another point of the Cluster 5 is located on the Xingu River, downstream of the confluence with the urban stream Panelas, which exhibits conditions of low environmental quality and it is a probable source of impact for Xingu River. In general, even if the water quality of the stations of this cluster is impacted by human activities and has high nutrient concentrations (mainly total nitrogen) and higher BOD than the other groups, the high power of dilution and depuration of the Xingu River quickly recovers the environmental conditions in downstream stations.

Water quality in the stations of Bacajá River, which formed Cluster 2 characterized by high loads of ions, conductivity and turbidity, were caused predominantly by the geochemical characteristics of the drainage basin as there is no degradation conditions on the surrounding of these points. The location of sampling stations $50 \mathrm{~km}$ away from the most important anthropogenic impact on Indigenous village Pykayaká reinforce the hole of the geochemical formation on the water quality in these stations.

Cluster 4 was characterized by stations with low concentration of ions and nutrients except $\mathrm{NO}_{3}{ }^{-}$and the CYANO. Probably the high values of these variables were caused by the contribution of streams located upstream of the sampling stations: 13_XR: Bacajá River, 14_XR: Paquiçamba Stream, and 18_XR: Tucuruí Stream. Apparently, these tributaries of the Xingu River have similar function of lateral lagoons, as some other rivers in the Amazon basin (e.g. Tocantins and Araguaia rivers), which are a source of organic matter to the Xingu River. Moreover, these streams with some anthropogenic influence could generate punctual contributions and deteriorate water quality downstream.

The stations belonging to Cluster 3 were those with better surface water quality in the study area. These points are located on the Xingu River in different parts of the study area, as well as in the Chocai Stream, exhibiting low nutrient concentrations, low ion concentration and low E. coli densities and high TRANSP, suggesting systems with high water quality. It is noteworthy that this Cluster concentrated most sampling points, indicating that if the local impacts generated by deterioration of the environment and / or inappropriate use of water in certain localities (e.g. Cluster 1) were removed, the good water quality would predominate. Another observation regarding the Cluster 1 stations was that they were far from point sources that could impact their water quality (e.g. anthropogenic impacts). Furthermore the surrounding conditions in these stations has a wide forest coverage, providing a mechanism to control diffuse loadings and maintain high water quality at these sites.

In contrast to the Andean tributaries of the Amazon River, which have turbid waters and higher concentrations of dissolved ions (resulting from weathering of geochemically richer rocks), the Xingu River has clearer water and lower ions concentrations. This is because its waters are originated from the Central Brazilian Shield, which geology is characterized by tertiary sediments derived from highly leached and geochemically poor Precambrian rocks, and by the fact that the basin has stable processes of erosion and sedimentation (Sioli, 1984).

In order to compare the features of the Xingu River Basin clear waters with whitewaters, darkwaters and clearwaters of other Amazonian rivers, a table containing $\mathrm{pH}$ and ions concentrations observed by several authors is presented (Table 5). The clearwaters observed in the Xingu basin were separated according to the clusters obtained in this study, including urban streams (Cluster 1), the Bacajá River (Cluster 2), and four distinct clusters observed in the Xingu River. Values observed in the Xingu River were similar to values found in literature for clear waters of the Tapajós River, with low concentrations of sulfate, calcium and carbonate and, quite distinct from whitewater of the Madeira and Solimões rivers. These results indicate that, although belonging to the same basin, the different portions of the Xingu River and its tributaries have different chemical characteristics, influenced by both the lithology of the drainage basin and the existing anthropogenic impacts.

In accordance with the results presented here, we detected high spatial variation of surface water quality in the study area. Such variations were caused by the specificity of the surroundings (landscape), water use, human activities and geochemical characteristics of the drained basins. It can be stated that most of the sampling stations in the Xingu River Basin in the studied area had high quality of surface water due to the absence of local impacts and high power of depuration of the Xingu River. The results are of great importance because they are original and they describe an Amazonian lotic system in good condition. However, after the impoundment Belo Monte dam, several changes will occur on this basin due permanent modification in the hydrological cycle. Some expected consequences as increase in residence time of the water and flooding of alluvial ecosystems will strongly influence water quality, 
Table 5. Concentration of major ions in different water types of the Amazonian rivers. Ions concentration in $\mu \mathrm{mol} \mathrm{L}^{-1}$.

\begin{tabular}{|c|c|c|c|c|c|c|c|c|c|c|c|}
\hline Water body & $\begin{array}{l}\text { Water } \\
\text { type* }\end{array}$ & pH & $\mathrm{NO}_{3}^{-}$ & $\mathrm{SO}_{-}$ & $\mathrm{HCO}_{3}^{-}$ & $\mathrm{Cl}^{-}$ & $\mathbf{K}^{+}$ & $\mathrm{Na}^{+}$ & $\mathbf{C a}^{++}$ & $\mathbf{M g}^{++}$ & Reference \\
\hline Negro River & Blackwater & 4.84 & - & 0.73 & 65.08 & 55.14 & 18.21 & 54.78 & 21.00 & 5.83 & Silva et al. (2011) \\
\hline Madeira River & Whitewater & 6.90 & - & 48.33 & 395.08 & 14.57 & 33.85 & 107.39 & 112.50 & 72.08 & Silva et al. (2011) \\
\hline Solimões River & Whitewater & 6.70 & - & 73.96 & 409.84 & 17.14 & 25.64 & 130.43 & 257.50 & 54.17 & $\begin{array}{l}\text { Queiróz et al. } \\
\text { (2009) }\end{array}$ \\
\hline $\begin{array}{l}\text { Amazon River before } \\
\text { Madeira River }\end{array}$ & Whitewater & 6.29 & - & 16.67 & 345.08 & 51.71 & 21.79 & 118.26 & 151.50 & 34.17 & Silva et al. (2011) \\
\hline $\begin{array}{l}\text { Amazon River after } \\
\text { Madeira River }\end{array}$ & Whitewater & 6.86 & - & 36.88 & 480.00 & 50.86 & 26.41 & 102.17 & 161.75 & 46.25 & Silva et al. (2011) \\
\hline Trombetas River & Clearwater & 5.86 & - & 3.65 & 330.00 & 16.86 & 17.95 & 41.30 & 12.00 & 7.92 & Silva et al. (2011) \\
\hline Tapajós River & Clearwater & 6.80 & - & 21.56 & 370.00 & 10.29 & 20.00 & 35.65 & 24.50 & 20.83 & Silva et al. (2011) \\
\hline $\begin{array}{l}\text { CLUSTER } 1 \text { - urban } \\
\text { streams }\end{array}$ & Clearwater & 6.22 & 8.40 & 5.37 & 172.95 & 74.68 & 16.25 & 100.61 & 36.06 & 23.26 & Present study \\
\hline $\begin{array}{l}\text { CLUSTER } 2 \text { - Bacajá } \\
\text { River }\end{array}$ & Clearwater & 7.23 & 10.61 & 4.93 & 200.86 & 85.09 & 50.02 & 245.18 & 91.88 & 79.65 & Present study \\
\hline $\begin{array}{l}\text { CLUSTER } 3 \text { - Xingu } \\
\text { River and Chocai Stream }\end{array}$ & Clearwater & 6.95 & 4.63 & 1.91 & 76.62 & 28.01 & 26.60 & 83.24 & 43.13 & 27.52 & Present study \\
\hline $\begin{array}{l}\text { CLUSTER } 4 \text { - Xingu } \\
\text { River }\end{array}$ & Clearwater & 7.06 & 4.97 & 2.58 & 110.30 & 41.71 & 33.04 & 124.78 & 51.18 & 39.17 & Present study \\
\hline $\begin{array}{l}\text { CLUSTER } 5 \text { - Xingu } \\
\text { River, downstream } \\
\text { anthropogenic impacts }\end{array}$ & Clearwater & 6.95 & 4.53 & 1.86 & 75.21 & 44.68 & 26.82 & 98.36 & 39.47 & 26.15 & Present study \\
\hline $\begin{array}{l}\text { CLUSTER } 6 \text { - Xingu } \\
\text { River }\end{array}$ & Clearwater & 6.83 & 5.58 & 3.54 & 78.19 & 27.31 & 26.36 & 83.21 & 42.85 & 27.76 & Present study \\
\hline Average - Xingu River & Clearwater & 6.95 & 4.93 & 2.47 & 85.08 & 35.43 & 28.21 & 97.40 & 44.16 & 30.15 & Present study \\
\hline
\end{tabular}

*based on the physical and chemical properties of Amazonian rivers according to Sioli (1984).

generating increase in the nutrients loads (e.g. phosphorous and nitrogen), increase in the turbidity and depletion of the dissolved oxygen. Thus, we believe that the greatest contribution of this study is to generate a robust baseline for comparisons after the impoundment Belo Monte dam, providing possibilities to monitoring projects and subsidies for an appropriate environmental management of the Xingu River basin.

\section{Acknowledgements}

The authors are thankful to Dr. Hugo Sarmento for his assistance throughout different stages of this work. The authors wish to express their thanks to Norte Energia S. A. for support and funding of the project. Also, Jorge Luiz Rodrigues-Filho would like to acknowledge Fundação de Amparo à Pesquisa do Estado de São Paulo (FAPESP/Process $n^{\circ}$ 2013/19602-0) for Post-doctoral fellowship at International Institute of Ecology and Environmental Management.

\section{References}

Agência Nacional de Águas - ANA, 2011. Plano estratégico de recursos hídricos da bacia amazônica: afluentes da margem direita. Brasilia: ANA. 825 p. Available from: $<$ http://arquivos.ana.gov.br/ institucional/sge/CEDOC/Catalogo/2013/planoEstrategicoDeRecursos. pdf>. Access in: 27 Mar. 2014.
ALLAN, JD., 2004. Landscapes and riverscapes: the influence of land use on stream ecosystems. Annual Review of Ecology Evolution and Systematics, vol. 35, no. 1, p. 257-284. http:// dx.doi.org/10.1146/annurev.ecolsys.35.120202.110122.

American Public Health Association - APHA, 1998. Standard methods for the examination of water and wastewater. Washington: APHA.

CAMARGO, M., GIARRIZZO, T. and ISAAC, V., 2004. Review of the geographic distribution of fish fauna of the Xingu River basin, Brazil. Ecotropica, vol. 10, p. 123-147.

Conselho Nacional do Meio Ambiente - CONAMA, 1987. Resolução Conama $n^{\circ}$ 6, de 16 de setembro de 1987. Dispõe sobre o licenciamento ambiental de obras do setor de geração de energia elétrica. Diário Oficial da União, Brasília, 22 out., Seção 1, p. 17500. Avaiable from: <http://www.mma.gov.br/ port/conama/legiabre.cfm?codlegi=57>. Access in: 27 Mar. 2015.

Consorcio Nacional de Engenheiros Consultores-CNEC, 1988. Estudo de Impacto Ambiental - EIA da UHE Kararaô. São Paulo: CNEC. no. 2.

Eletrobrás, 2009. AAI - Avaliação ambiental integrada aproveitamentos hidrelétricos da bacia hidrográfica do Rio Xingu. São Paulo: Eletrobrás. vol. 1, 204 p. Available from: < http://www.eletrobras. com.br/elb/services/DocumentManagement/FileDownload.EZTSvc. asp?DocumentID=\%7B183CB2DD-5282-4BC5-9504-285F4A6F 4158\%7D\&ServiceInstUID=07B9F99B54C-E9F1-479F-A9B0F08EFBF20600\%7D>. Access in: 27 Mar. 2014.

EVERITT, BS., LANDAU, S. and LEESE, M., 2001. Cluster analysis. Hoboken: John Wiley \& Sons. 
FITTKAU, EJ., 1970. Limnological conditions in the headwater regions of the Xingu River. Brazil. Tropical Ecology, vol. 11, no. 1, p. 20-25.

HAMMER, Ø., HARPER, DAT. and RYAN, PD., 2001. PAST: Paleontological statistics software package for education and data analysis. Palaeontologia Electronica, vol. 4, no. 1, p. 9.

Instituto Brasileiro de Geografia e Estatística - IBGE, Sistema IBGE de Recuperação Automática - SIDRA, 2010. Banco de Dados Agregados. Available from: http://www.sidra.ibge.gov. br/. Access in: 27 Mar. 2015.

Instituto Brasileiro de Geografia e Estatística - IBGE, Diretoria de Pesquisas, Coordenação de População e Indicadores Sociais, 2014. Available from: <http://www.ibge.gov.br/home/>. Access in: 27 Mar. 2015

ISCEN, CF., EMIROGLU, O., ILHAN, S., ARSLAN, N., YILMAZ, V. and AHISKA, S., 2008. Application of multivariate statistical techniques in the assessment of surface water quality in Uluabat Lake, Turkey. Environmental Monitoring and Assessment, vol. 144, no. 1-3, p. 269-276. http://dx.doi.org/10.1007/s10661-0079989-3. PMid:17929181.

JOLLIFFE, I., 1986. Principal component analysis. New York: Springer Verlag.

JOLLIFFE, IT., 1972. Discarding variables in a principal component analysis I: artificial data. Journal of Applied Statistics, vol. 21, no. 2, p. 160-173. http://dx.doi.org/10.2307/2346488.

LEGENDRE, P. and LEGENDRE, L., 1998. Developments in environmental modelling. In PIERRE, L. and LOUIS, L. Numerical ecology. Netherlands: Elsevier. 853 p.

Leme Engenharia, 2009. Diagnóstico das áreas diretamente afetadas e de influência direta: meio biótico - ecossistema aquático - qualidade da água e limnologia. 176 p. Estudo de Impacto Ambiental do AHE Belo Monte, vol. 15. Available from: $<$ http://licenciamento.ibama.gov.br/Hidreletricas/Belo\%20Monte/ Relatorios $\% 20$ Semestrais $/ 2 \% \mathrm{C} 2 \% \mathrm{BA} \% 20$ Relatorio\%20Semestral $\% 20$ Consolidado/CAP\%CDTULO $\% 202 \% 20-\% 20$ PLANOS, $\% 20$ PROGRAMAS\%20E\%20PROJETOS/10/10.4/10.4\%20-\%20 CAP\%202\%20-\%20FINAL.pdf $>$. Access in: 27 Mar. 2014.

LIKENS, GE., 1984. Beyond the shoreline: a watershed-ecosystem approach. Verhandlungen des Internationalen Verein Limnologie, vol. $22</$ jrn $>$.

LIKENS, GE., BORMANN, FH., JOHNSON, NM., FISHER, DW. and PIERCE, RS., 1970. Effects of Forest cut and herbicide treatment on nutrient budgets in the Hubbard-Brook watershed ecosystems. Ecological Monographs, vol. 40, no. 1, p. 23-77. http://dx.doi.org/10.2307/1942440.

MEYER, JL., PAUL, MJ. and TAULBEE, WK., 2005. Stream ecosystem function in urbanizing landscapes. Journal of the North American Benthological Society, vol. 24, no. 3, p. 602-612. http:// dx.doi.org/10.1899/0887-3593(2005)0240602:SEFIUL2.0.CO;2.

Brasil. Ministério Público Federal - MPF, 2010. Licença Prévia $n^{\circ} 342$ /2010. Availiable from: <http://www.prpa.mpf.mp.br/ news/2011/LP342-2010-Belo-Monte.pdf>. Acess in: 27 Mar. 2015.

NUSH, EA., 1980. Comparison of different methods for chlorophyll and phaeopigment determination. Archiv für HydrobiologieBeiheft, vol. 14, p. 14-39.

OUYANG, Y., NKEDI-KIZZA, P., WU, QT., SHINDE, D. and HUANG, CH., 2006. Assessment of seasonal variations in surface water quality. Water Research, vol. 40, no. 20, p. 3800-3810. http://dx.doi.org/10.1016/j.watres.2006.08.030. PMid:17069873.

PAUL, MJ. and MEYER, JL., 2001. STREAMS IN THE URBAN LANDSCAPE. Annual Review of Ecology and Systematics, vol. 32, no. 1, p. 333-365. http://dx.doi.org/10.1146/annurev. ecolsys.32.081501.114040.

QUEIROZ, MMA., HORBE, AMC., SEYLER, P. and MOURA, CAV., 2009. The Solimões river hydrochemistry between Manacapuru and Alvarães- Amazonas-Brazil. Acta Amazonica, vol. 39 , no. 4, p. $943-952$.

TUNDISI, JG., MATSUMURA-TUNDISI, T., TUNDISI, JEM., FARIA, CRL., ABE, DS., BLANCO, F., RODRIGUES FILHO, J., CAMPANELLI, L., SIDAGIS GALLI, C., TEIXEIRA-SILVA, V., DEGANI, R., SOARES, FS. and GATTI JUNIOR, P., 2015. Limnological and ecological methods: approaches, and sampling strategies for middle Xingu River in the area of influence of future Belo Monte Power Plant. Brazilian Journal of Biology, vol. 75, no. 3, supplement, p. S16-S29.

SANTOS, SMSBM. and HERNÁNDEZ, FDM., 2009. Painel de especialistas: análise crítica do estudo de impacto ambiental do aproveitamento hidrelétrico de Belo Monte. Available from: $<$ http://www.xinguvivo.org.br/wp-content/uploads/2010/10/ Belo_Monte_Painel_especialistas_EIA.pdf $>$. Access in: 27 Mar. 2015.

SEVÁ FILHO, AO., 2005. TENOTÃ-MÕ: Alertas sobre as conseqüencias dos projetos hidrelétricos no rio Xingu. São Paulo: International Rivers Network. 344 p.

SHELDON, F., PETERSON, EE., BOONE, EL., SIPPEL, S., BUNN, SE. and HARCH, BD., 2012. Identifying the spatial scale of land use that most strongly influences overall river ecosystem health score. Ecological Applications, vol. 22, no. 8, p. 2188-2203. http://dx.doi.org/10.1890/11-1792.1. PMid:23387119.

SILVA, MSR., CUNHA HB., MIRANDA SAF., SANTANA, GP. and PASCOALOTO, D., 2011. Química das águas de superifície os rios da Bacia Amazônica: uma contribuição para classificação de acordo com seus usos preponderantes. In XIX Simpósio Brasileiro de Recursos Hidricos, 2011. Maceió. Maceió: ABRH.

SIMEONOVA, P., SIMEONOV, V. and ANDREEV, G., 2003. Water quality study of the Struma river basin, Bulgaria (1989-1998). Central European Journal of Chemistry, vol. 1, no. 2, p. 121-136.

SIOLI, H., 1950. Das wasser in Amazonasgebeit. Forschung Fortchrift, vol. 26, p. 274-280.

SIOLI, H., 1984. The Amazon: limnology and landscape ecology of a mighty tropical river and its basin. Internationale Revue der Gesamten Hydrobiologie und Hydrographie, vol. 56, p. 762.

TUNDISI, JG. and STRAŠKRABA, M., 1999. Theoretical reservoir ecology and its applications. Hamburg: International Institute of Ecology. 265 p.

TUNDISI, JG., 2007. Exploração do potencial hidrelétrico da Amazônia. Estudos Avançados, vol. 21, no. 59, p. 109-117. http:// dx.doi.org/10.1590/S0103-40142007000100009.

TUNDISI, JG., MATSUMURA-TUNDISI, T. and ABE, DS., 2008. The ecological dynamics of Barra Bonita (Tietê River, SP, Brazil) reservoir: implications for its biodiversity. Brazilian Journal of Biology, vol. 68, no. 4, supplement, p. 1079-1098. http://dx.doi. org/10.1590/S1519-69842008000500015. PMid:19197478. 
TURNER, MG., GARDNER, RH. and O'NEILL, RV., 2001. Landscape ecology in theory and practice: pattern and process. Heidelberg: Springer. 406 p.

VALDERRAMA, JC., 1981. The simultaneous analisys of total nitrogen and phosphorus in natural waters. Marine Chemistry, vol. 10, p. 109-122.

WARD, JV., BRETSCHKO, G., BRUNKE, M., DANIELOPOL, D., GIBERT, J., GONSER, T. and HILDREW, AG., 1998. The boundaries of river systems: the metazoan perspective. Freshwater Biology, vol. 40, no. 3, p. 531-569. http://dx.doi.org/10.1046/j.13652427.1998.00368.x.

WETZEL, RG., 2001. Limnology: lake and river ecosystems. San Diego: Academic Press.

WETZEL, RG. and LIKENS, GE., 1991. Limnological analyses. Heidelberg: Springer-Verlag. 391 p.
WIENS, JA., 1989. Spatial scaling in ecology. Functional Ecology, vol. 3, no. 4, p. 385-397. http://dx.doi.org/10.2307/2389612.

ZALEWSKI, M., 2000. Ecohydrology: the scientific background to use ecosystem properties as management tools toward sustainability of water resources. Ecological Engineering, vol. 16, no. 1, p. 1-8. http://dx.doi.org/10.1016/S0925-8574(00)00071-9.

ZAR, JH., 2010. Biostatistical analysis. Upper Saddle River: Prentice Hall.

ZHAO, J., FU, G., LEI, K. and LI, Y., 2011. Multivariate analysis of surface water quality in the Three Gorges area of China and implications for water management. Journal of Environmental Sciences, vol. 23, no. 9, p. 1460-1471. http://dx.doi.org/10.1016/ S1001-0742(10)60599-2. PMid:22432281. 